\title{
PENGARUH KONSENTRASI EKSTRAK BAWANG MERAH DAN AIR KELAPA TERHADAP PERTUMBUHAN STEK PUCUK JAMBU AIR MADU DELI HIJAU (Syzygium samarangense)
}

\author{
The Effect of Shallot Extract and Concentration of Coconut Water on The Growth of Shoot- \\ Cutting of Green Deli Rose Apples (Syzygium samarangense)
}

\author{
Nabila Nur Aisyah Al Ayyubi ${ }^{*}$, Bambang Kusmanadhi, Tri Agus Siswoyo \\ dan Yagus Wijayanto
}

\author{
Program Studi Agroteknologi, Fakultas Pertanian, Universitas Jember \\ Jalan Kalimantan 37, Kampus Tegal Boto, Jember 68121 \\ *E-mail:nabilanaaa@gmail.com
}

\begin{abstract}
Green Deli Rose Apples (Syzygium samarangense) has several beneficial properties in terms of usability, cultivation, health, and economy. The intensive development of green deli rose apples plants is needed given increasing demand, needs, and has bright prospects. One of the efforts to develop green deli rose apples plants is through handling plant propagation. Propagation of green deli rose apples can be done in two ways, namely generative and vegetative. Generative propagation requires a relatively long time, while vegetative propagation have difficult to growth in rooted. Shoot-cuttings is one of the vegetative propagation that has been chosen because it is easier to root than the old parts of the plant. The use of plant growth regulators (PGR) is needed to stimulate green deli rose apples shoot-cuttings rooting. Alternative PGR is giving shallot extract and coconut water as a substitute for synthetic auxin which has a relatively expensive price. The purpose of this study was to determine the combination of the effect of the concentration shallot extract and coconut water, as well as to find out the concentration of shallot extracts and coconut water which was most influential on the growth of shoot-cutting of green deli rose apples. The extract shallot concentration used is control, $0,5 \%, 1,0 \%$, and $1,5 \%$. The coconut water concentration used is control, $20 \%, 30 \%$ and $40 \%$. Data obtained next analyzed and tested using DMRT $\alpha 5 \%$. The result showed te best treatment combination for concentration shallot extract of $0,5 \%$ and coconut water of $20 \%$.
\end{abstract}

Keywords: greend deli rose apples, shoot-cutting, shallot extract, coconut water

\section{ABSTRAK}

Jambu air madu deli hijau (MDH) (Syzygium samarangense) memiliki beberapa sifat yang menguntungkan baik dari segi kegunaan, budidaya, kesehatan, maupun ekonomi. Pengembangan tanaman secara intensif diperlukan mengingat permintaan dan kebutuhan yang semakin meningkat, serta memiliki prospek yang cerah. Salah satu usaha pengembangan tanaman yaitu melalui penanganan perbanyakan tanaman. Perbanyakan dapat dilakukan dengan dua cara yaitu generatif dan vegetatif. Perbanyakan secara generatif membutuhkan waktu yang relatif lama, sedangkan perbanyakan vegetatif memiliki kendala sulit membentuk perakaran. Stek pucuk merupakan salah satu perbanyakan vegetatif yang banyak dipilih karena lebih mudah berakar dibandingkan bagian tanaman tua. Penggunaan zat pengatur tumbuh (ZPT) diperlukan untuk merangsang perakaran stek pucuk jambu air MDH. Alternatif ZPT yaitu pemberian ekstrak bawang merah dan air kelapa sebagai pengganti auksin sintetis yang memiliki harga relatif mahal. Penelitian ini bertujuan untuk mengetahui kombinasi pengaruh konsentrasi ekstrak bawang merah dan air kelapa terhadap pertumbuhan stek pucuk jambu air $\mathrm{MDH}$, serta mengetahui konsentrasi ekstrak bawang merah dan air kelapa yang paling berpengaruh terhadap pertumbuhan stek pucuk jambu air MDH. Konsentrasi ekstrak bawang merah yang digunakan antara lain kontrol, $0,5 \%, 1 \%$ dan $1,5 \%$. Konsentrasi air kelapa yang digunakan antara lain kontrol, $20 \%, 30 \%$, dan $40 \%$. Data yang diperoleh selanjutnya dianalisis dan diuji menggunakan DMRT $\alpha 5 \%$. Hasil penelitian menunjukkan kombinasi perlakuan terbaik untuk konsentrasi ekstrak bawang merah dan air kelapa adalah konsentrasi $0,5 \%$ dan air kelapa $20 \%$.

Kata Kunci: jambu air madu deli hijau, stek pucuk, ekstrak bawang merah, air kelapa

How to citate: Ayyubi, N. N. A. A., B. Kusmanadhi, T. A. Siswoyo dan Y. Wijayanto. 2019. Pengaruh Konsentrasi Ekstrak Bawang Merah dan Air Kelapa Terhadap Pertumbuhan Stek Pucuk Jambu Air Madu Deli Hijau (Syzygium samarangense). Berkala Ilmiah Pertanian 2(1): 19-25.

\section{PENDAHULUAN}

Jambu air madu deli hijau (Syzygium samarangense) termasuk ke dalam suku jambu-jambu atau Myrtaceae yang merupakan kultivar unggul hasil introduksi. Penanaman jambu air hampir meluas diseluruh wilayah Indonesia, khususnya di Pulau Jawa sebagai tempat pusat penyebaran (Mulyani dan Ismail, 2015). Hal ini dikarenakan jambu air madu deli hijau termasuk tanaman buahbuahan yang dikomsumsi sebagai buah segar, maupun rujak dan asinan. Keuntungan lainnya antara lain cara budidaya yang mudah, produksi buah yang tinggi, memiliki harga jual relatif mahal, memiliki rasa manis hingga 15 Brix, gizi yang cukup tinggi dan memiliki bobot buah yang cukup besar yaitu 1,5-2 ons. Kandungan gizi dalam 100 gram yaitu kadar air sekitar $81,59 \%$, kadar vitamin C $210,463 \mathrm{mg} / 100 \mathrm{~g}$, dan tekstur daging $0,830 \mathrm{~g} / \mathrm{mm}^{2}$ (Karo- karo et al., 2015). Harga jual di pasar juga terus meningkat setiap tahunnya mulai dari harga $\mathrm{Rp} 25.000-49.000$ per kg dengan permintaan yang semakin meningkat (Rangkuti et al., 2016). Pengembangan tanaman secara intensif diperlukan mengingat permintaan dan kebutuhan yang semakin meningkat, serta memiliki prospek yang cerah untuk dikembangkan secara intensif (monokultur) (Karo-karo et al., 2015).

Pengembangan tanaman jambu air madu deli hijau perlu dukungan ketersediaan bibit yang berkualitas dalam jumlah yang cukup, akan tetapi masih banyak petani tradisional yang sering mengabaikan penanganan perbanyakan tanaman. Apabila perbanyakan tanaman dilakukan tepat, maka akan menguntungkan 
sebagai suatu usaha tani. Perbanyakan tanaman jambu air madu deli hijau dapat dilakukan dengan dua cara yaitu secara generatif dan secara vegetatif. Stek merupakan salah satu perbanyakan vegetatif yang memanfaatkan bagian tanaman (akar, batang, dan tunas) dengan beberapa perlakuan dengan tujuan agar bagian tersebut membentuk akar. Keuntungan stek sebagai alternatif yang dipilih karena memiliki sifat sama dengan induknya, dan biaya lebih murah. Perbanyakan melalui stek pucuk memiliki permasalahan yaitu perakaran yang sulit tumbuh, sehingga diperlukan zat pengatur tumbuh (ZPT) untuk merangsang pertumbuhan akar. Stek memiliki beberapa macam yaitu stek daun, stek batang, stek pucuk, dan lain sebagainya. Stek bagian tanaman muda atau pucuk akan lebih mudah berakar dibandingkan bagian tanaman tua (Mulyani dan Ismail, 2015). Pemberian zat pengatur tumbuh (ZPT) diperlukan untuk mendorong, merangsang, dan mempercepat pembentuk akar, serta meningkatkan mutu akar dan jumlah akar (Sinaga et al., 2015).

Zat pengatur tumbuh (ZPT) merupakan senyawa organik yang efektif merangsang perakaran pada konsentrasi tertentu. ZPT berdasarkan sumbernya dapat diperoleh secara alami maupun sintetis. Menurut Sudomo et al. (2013), penggunaan auksin sintetis terbukti dapat meningkatkan rata-rata jumlah tunas, jumlah akar, dan panjang akar pada stek pucuk manglid. Sitokinin sintetis juga dapat meningkatkan pertumbuhan tanaman, Hadiati (2011) menyatakan bahwa perendaman stek batang nenas (Ananas comosus L.) dalam larutan BAP berpengaruh nyata terhadap parameter jumlah daun, tinggi tunas, dan pecah tunas. Auksin dan sitokinin sintetis tersebut merupakan ZPT yang sering digunakan untuk merangsang perakaran, namun memiliki harga relatif mahal.

Bawang merah dapat digunakan sebagai pengganti auksin sintetis karena memiliki kandungan minyak atsiri, sikloaliin, metilaliin, dihidroaliin, flavonglikosida, kuersetin, saponin, peptida, fitohormon, vitamin dan zat pati. Fitohormon yang terkandung pada bawang merah yaitu auksin dan giberelin (Muswita, 2011). Hasil penelitian Muswita (2011) menunjukkan bahwa pemberian ekstrak bawang merah pada konsentrasi $1,0 \%$ merupakan konsentrasi optimal untuk presentase stek hidup dan konsentrasi $0,5 \%$ merupakan konsentrasi optimal untuk jumlah akar stek tanaman gaharu (Aquilaria malaccencis Oken). Air kelapa juga dikenal sebagai zat perangsang tumbuh alami dalam perbanyakan dengan stek. Kandungan air kelapa antara lain auksin mencapai $60 \%$ dan sitokinin mencapai 20\% (Khair et al., 2013). Hasil penelitian Djamhuri (2011) menunjukkan bahwa pemberian air kelapa pada stek pucuk meranti tembaga (Shorea leprosula Miq.) dapat meningkatkan presentase stek hidup, persentase akar, persentase bertunas, dan berat kering akar. Berdasarkan uraian tersebut, maka perlu dilakukan penelitian mengenai konsentrasi bawang merah dan air kelapa yang tepat untuk mengetahui pengaruhnya terhadap pertumbuhan stek pucuk jambu air madu deli hijau (Syzygium samarangense).

\section{BAHAN DAN METODE}

Waktu dan Tempat. Penelitian dilaksanakan pada bulan Maret 2019 sampai dengan Juni 2019, bertempat di Kelurahan Tegalgede, Kecamatan Sumbersari, Kabupaten Jember.

Alat dan Bahan. Bahan stek jambu air varietas madu deli hijau (Syzygium samarangese), ZPT alami (air kelapa dan ekstrak bawang merah), oasis, cup plastik berukuran diameter $7 \mathrm{~cm}$, dan fungisida Dithane M-45, terpal plastic warna putih, paranet $70 \%$, tali rafia, bambu, benang, lakban, pisau, papan nama, gunting pangkas, ember, hand sprayer, gelas ukur, timbangan analitik, alat tulis, dan alat dokumentasi.

Metode Percobaan. Rancangan percobaan menggunakan Rancangan Acak Lengkap (RAL) Faktorial yang terdiri dari 2 faktor. Faktor pertama konsentrasi ekstrak bawang merah yaitu $\mathrm{A} 0=$ kontrol, $\mathrm{A} 1=0,5 \%(5 \mathrm{ml} /$ liter aquadest $), \mathrm{A} 2=1,0 \%(10 \mathrm{ml} / \mathrm{liter}$ aquadest), dan $\mathrm{A} 3=1,5 \%$ ( $15 \mathrm{ml} /$ liter aquadest). Faktor kedua konsentrasi air kelapa yaitu B0=kontrol, B1 $=20 \%(200 \mathrm{ml} / \mathrm{liter}$ aquadest), dan B2=30\% (300 ml/liter aquadest), dan B3=40\% (400 $\mathrm{ml} /$ liter aquadest). Setiap kombinasi perlakuan diulang sebanyak 3 kali sehingga didapatkan 48 satuan percobaan. Data hasil pengamatan selanjutnya dianalisis dengan menggunakan analisis sidik ragam (ANOVA). Apabila hasil dari analisis menunjukkan pengaruh nyata maka dilanjutkan dengan Uji Duncan Multiple Range Test (DMRT) dengan taraf kesalahan sebesar 5\%.

Persiapan Lokasi. Pembersihan lokasi dari gulma, meratakan permukaan yang bergelombang, membuat tinggi $\pm 10 \mathrm{~cm}$, dan membuat petakan-petakan pembatas.

Pembuatan Sungkup. Pembuatan sungkup menggunakan bahan bambu dengan ukuran $330 \mathrm{~cm}$ x $180 \mathrm{~cm}$ x $100 \mathrm{~cm}$. Sungkup tersebut secara kesuluruhan ditutup dengan plastik bening.

Persiapan Media Tanam. Petak besar oasis dilakukan pemotongan menggunakan pisau dengan ukuran $2 \mathrm{~cm} \times 3 \mathrm{~cm} \times 5$ $\mathrm{cm}$, kemudian direndam dengan air hingga basah sempurna dan dapat digunakan sebagai media tanam.

Pengambilan Bahan Stek. Bahan stek pucuk yang dipilih yaitu cabang memiliki daun sudah berwarna hijau sedikit tua dan dilakukan pemotongan panjang 3 ruas. Daun disisakan dua pasang pada bagian ruas atas, kemudian dilakukan pemotongan kurang lebih setengah bagian dari ukuran penuh daun.

Perlakuan Ekstrak Bawang Merah. Pembuatan konsentrasi ekstrak bawang merah dilakukan dengan cara membersihkan, kemudian dihancurkan menggunakan blender. Hasil bawang tersebut kemudian disaring menggunakan kain, kemudian dilakukan pemerasan untuk diambil ekstraknya atau air dan ditampung didalam baskom. Ukuran pembuatan ekstrak bawang merah tersebut menggunakan sebanyak 250 gram umbi bawang merah sebagai larutan stok dengan konsentrasi $100 \%$, kemudian untuk aplikasi pada tanaman dilakukan dengan mengencerkan larutan stok tersebut sesuai dengan perlakuan konsentrasi yang ditetapkan. Aplikasi perlakuan ekstrak bawang merah pada stek jambu madu deli hijau dilakukan dengan cara perendaman selama 6 jam sebelum ditanam pada media oasis (Mendrofa, 2018).

Perlakuan Air Kelapa. Pembuatan air kelapa dilakukan dengan mengencerkan air kelapa muda dengan aquadest sesuai dengan konsentrasi perlakuan yang ditetapkan. Aplikasi air kelapa pada stek dilakukan dengan disiram pada media tanam. Penyiraman air kelapa dilakukan setiap 7 hari sekali sesuai konsentrasi yang ditetapkan sebanyak $10 \mathrm{ml} /$ stek.

Penanaman. Stek pucuk yang akan ditanam pada media oasis yang telah disiapkan. Media oasis yang siap ditanam memiliki ciri telah basah sempurna setelah perendaman dengan air. Penanaman stek pucuk kemudian dilakukan dengan menancapkan stek ke dalam $3 / 4$ media oasis tersebut.

Pemeliharaan. Pemeliharaan stek dilakukan dengan pencegahan organisme penganggu tanaman (OPT), penyiraman, dan sanitasi. Pencegahan OPT dilakukan dengan menggunakan fungsida Dithane M-45. Penyiraman stek dilakukan dua kali sehari pada waktu pagi dan sore hari bertujuan untuk mempertahankan kelembaban

Variabel pengamatan. terdiri dari: presentase stek bertunas, waktu terbentuknya tunas, panjang tunas, jumlah daun, luas daun. panjang akar, jumlah akar, berat kering akar, dan berat kering daun.

\section{HASIL DAN PEMBAHASAN}

\section{Presentase Stek Bertunas}

Berdasarkan data setelah dilakukan transformasi arc sin menunjukkan tidak berbeda nyata terhadap interaksi ekstrak bawang merah dan air kelapa, pengaruh ekstrak bawang merah, dan pengaruh air kelapa. Hal ini dikarenakan semua stek bertunas $(100 \%)$.

\section{Waktu Terbentuknya Tunas}

Waktu terbentuknya tunas merupakan variabel yang dilakukan pengamatan setiap hari untuk dapat mengetahui kecepatan bertunas pada pertumbuhan stek. Perlakuan kombinasi konsentrasi ekstrak bawang merah dengan perlakuan konsentrasi air kelapa memberikan pengaruh berbeda nyata terhadap variabel waktu terbentuknya tunas. Hasil tersebut dapat dilihat pada (Tabel 1).

Tabel 1. Interaksi Konsentrasi Ekstrak Bawang Merah dan Air Kelapa terhadap Variabel Waktu Terbentuknya Tunas (hari) 


\begin{tabular}{ccccc}
\hline Ekstrak & \multicolumn{4}{c}{ Air Kelapa } \\
\cline { 2 - 5 } Bawang Merah & B0 & B1 & B2 & B3 \\
\hline A0 & $12,67 \mathrm{a}$ & $7,33 \mathrm{c}$ & $7,67 \mathrm{c}$ & $10,67 \mathrm{~b}$ \\
& $\mathrm{~A}$ & $\mathrm{~A}$ & $\mathrm{~A}$ & $\mathrm{~A}$ \\
$\mathrm{~A} 1$ & $7,33 \mathrm{a}$ & $5,00 \mathrm{~b}$ & $6,00 \mathrm{a}$ & $6,33 \mathrm{a}$ \\
& $\mathrm{C}$ & $\mathrm{AB}$ & $\mathrm{B}$ & $\mathrm{B}$ \\
$\mathrm{A} 2$ & $8,67 \mathrm{a}$ & $6,33 \mathrm{~b}$ & $8,33 \mathrm{a}$ & $9,00 \mathrm{a}$ \\
& $\mathrm{C}$ & $\mathrm{AB}$ & $\mathrm{AB}$ & $\mathrm{A}$ \\
$\mathrm{A} 3$ & $10,67 \mathrm{a}$ & $6,67 \mathrm{c}$ & $8,67 \mathrm{~b}$ & $9,33 \mathrm{a}$ \\
& $\mathrm{B}$ & $\mathrm{B}$ & $\mathrm{AB}$ & $\mathrm{A}$ \\
\hline
\end{tabular}

Keterangan : Angka yang diikuti huruf kecil yang sama pada baris yang sama dan huruf besar yang sama pada kolom yang sama menunjukkan tidak berbeda nyata menurut uji DMRT $\alpha 5 \%$.

Berdasarkan hasil uji jarak berganda Duncan (DMRT $\alpha$ 5\%) (Tabel 1) menunjukkan interaksi pada perlakuan konsentrasi ekstrak bawang merah dan air kelapa terhadap waktu terbentuknya tunas. Pada A0 yang sama menunjukkan bahwa B1 memiliki waktu terbentuknya tercepat yakni 7,33 hari tidak berbeda nyata dengan B2, tetapi berbeda nyata dengan B3 dan B0. Pada A1 yang sama menunjukkan bahwa B1 memiliki waktu terbentuknya tercepat yakni 5,00 hari berbeda nyata terhadap B2, B3, dan B0. Pada A2 yang sama menunjukkan bahwa B1 memiliki waktu terbentuknya tercepat yakni 6,33 hari berbeda nyata terhadap B2, B3, dan B0. Pada A3 yang sama menunjukkan bahwa B1 memiliki waktu terbentuknya tercepat yakni 6,67 hari berbeda nyata terhadap B2, $\mathrm{B} 3$, dan B0.

Berdasarkan hasil uji jarak berganda Duncan (DMRT $\alpha$ 5\%) (Tabel 1) menunjukkan interaksi pada perlakuan konsentrasi ekstrak bawang merah dan air kelapa terhadap waktu terbentuknya tunas. Pada B0 yang sama menunjukkan bahwa A1 memiliki waktu terbentuknya tercepat yakni 7,33 hari tidak berbeda nyata dengan A2, tetapi berbeda nyata dengan A3 dan A0. Pada B1 yang sama menunjukkan bahwa A1 memiliki waktu terbentuknya tercepat yakni 5,00 hari berbeda nyata terhadap A2, A3, dan A0. Pada B2 yang sama menunjukkan bahwa B1 memiliki waktu terbentuknya tercepat yakni 6,00 hari berbeda nyata terhadap A2, A3, dan A0. Pada B3 yang sama menunjukkan bahwa A1 memiliki waktu terbentuknya tercepat yakni 6,33 hari berbeda nyata terhadap B2, B3, dan B0.

\section{Panjang Tunas}

Perlakuan konsentrasi ekstrak bawang merah dan perlakuan air kelapa memberikan pengaruh berbeda sangat nyata terhadap variabel panjang tunas, akan tetapi interaksi kedua perlakuan memberikan pengaruh berbeda tidak nyata terhadap variabel panjang tunas.

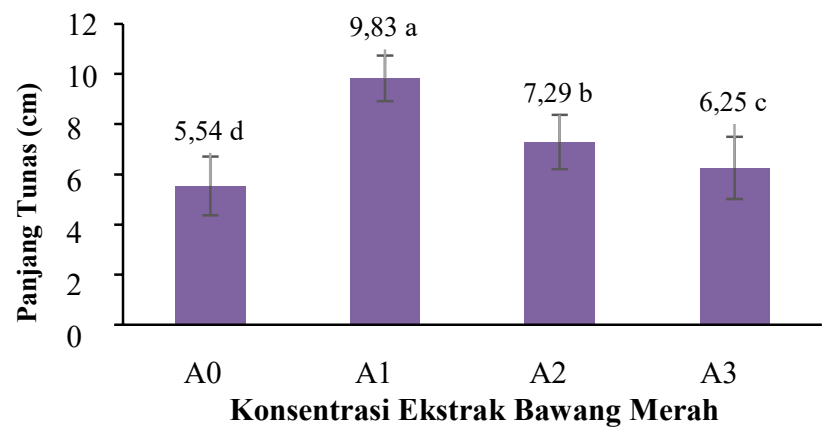

Gambar 1. Pengaruh Konsentrasi Ekstrak Bawang Merah terhadap Variabel Panjang Tunas

Berdasarkan hasil uji jarak berganda Duncan (DMRT $\alpha$ 5\%) (Gambar 1) menunjukkan bahwa terdapat perbedaan yang nyata pada semua perlakuan ekstrak bawang merah. Perlakuan konsentrasi ekstrak bawang merah sebesar $0,5 \%$ (A1) menunjukkan rata-rata panjang tunas tertinggi yakni sebesar $9,83 \mathrm{~cm}$, sedangkan terendah pada perlakuan kontrol (A0) sebesar $5,54 \mathrm{~cm}$. Perbedaan antara perlakuan ekstrak bawang merah konsentrasi $0,5 \%$ (A1) dengan konsentrasi kontrol (A0) menunjukkan selisih rata-rata panjang tunas sebesar 4,29 cm. Perlakuan konsentrasi ekstrak bawang merah sebesar $0,5 \%$ (A1) menunjukkan hasil yang lebih baik dibandingkan dengan kontrol (A0), konsentrasi 1,0\% (A2), dan konsentrasi 1,5\% (A3).

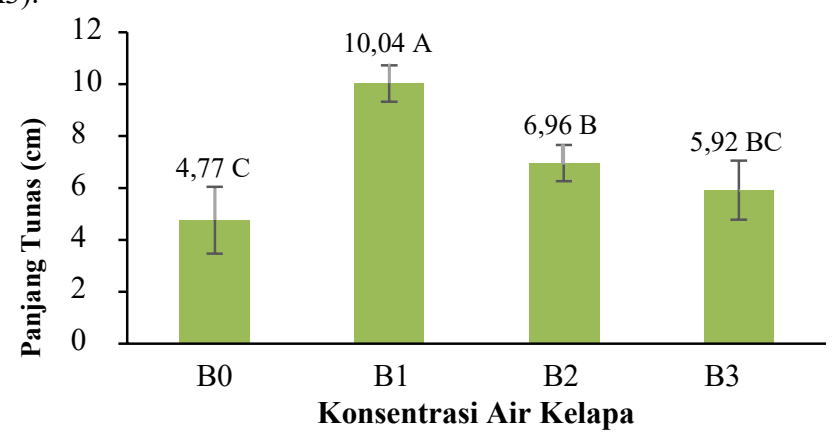

Gambar 2. Pengaruh Konsentrasi Air Kelapa terhadap Variabel Panjang Tunas

Berdasarkan hasil uji berganda Duncan (DMRT $\alpha$ 5\%) (Gambar 2) menunjukkan bahwa terdapat perbedaan yang nyata pada semua perlakuan konsentrasi air kelapa. Perlakuan konsentrasi air kelapa sebesar 20\% (B1) menunjukkan rata- rata panjang tunas tertinggi yakni sebesar $10,04 \mathrm{~cm}$, sedangkan terendah pada perlakuan konsentrasi kontrol (B0) sebesar $4,77 \mathrm{~cm}$. Perbedaan antara perlakuan air kelapa konsentrasi $20 \%$ (B1) dengan konsentrasi kontrol (B0) menunjukkan selisih rata-rata panjang tunas sebesar $5,27 \mathrm{~cm}$. Perlakuan konsentrasi air kelapa sebesar $20 \%$ (B1) menunjukkan hasil yang lebih baik dibandingkan dengan kontrol (B0), perlakuan konsentrasi 30\% (B2), dan konsentrasi $40 \%$ (B3).

\section{Jumlah Daun}

Jumlah daun merupakan salah satu variabel pengamatan yang digunakan untuk menunjukkan kondisi pertumbuhan suatu tanaman. Perlakuan air kelapa memberikan pengaruh berbeda sangat nyata terhadap variabel jumlah daun, akan tetapi interaksi kedua perlakuan dan pengaruh tunggal ekstrak bawang merah memberikan pengaruh berbeda tidak nyata, terhadap variabel jumlah daun.

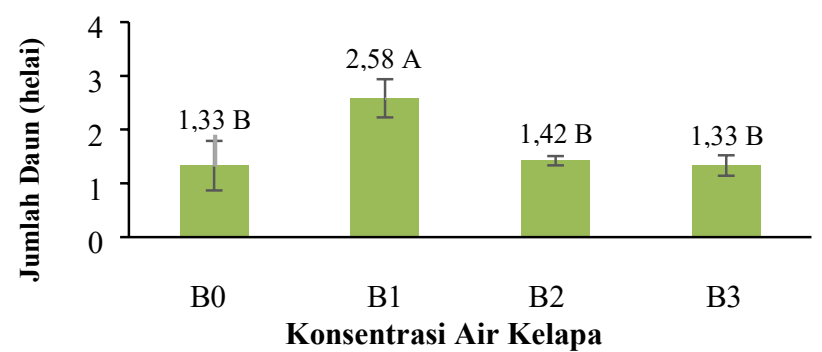

Gambar 3. Pengaruh Konsentrasi Air Kelapa Variabel Jumlah Daun

Berdasarkan hasil uji berganda Duncan (DMRT $\alpha$ 5\%) (Gambar 3) menunjukkan bahwa terdapat perbedaan yang nyata pada semua perlakuan konsentrasi air kelapa. Perlakuan konsentrasi air kelapa sebesar $20 \%$ (B1) menunjukkan rata- rata jumlah daun terbanyak yakni sebesar 2,58 helai, sedangkan paling sedikit pada perlakuan konsentrasi kontrol (B0) sebesar 1,33 helai. Perbedaan antara perlakuan air kelapa konsentrasi $20 \%$ (B1) dengan konsentrasi kontrol (B0) menunjukkan selisih rata-rata jumlah daun sebesar 1,25 helai. Perlakuan konsentrasi air kelapa sebesar 20\% (B1) menunjukkan hasil yang lebih baik dibandingkan dengan kontrol (B0), perlakuan konsentrasi 30\% (B2), dan konsentrasi 40\% (B3).

\section{Luas Daun}

Perlakuan konsentrasi ekstrak bawang merah dan perlakuan air kelapa memberikan pengaruh berbeda sangat nyata terhadap variabel luas daun, akan tetapi interaksi kedua perlakuan memberikan pengaruh berbeda tidak nyata terhadap variabel luas 
daun.

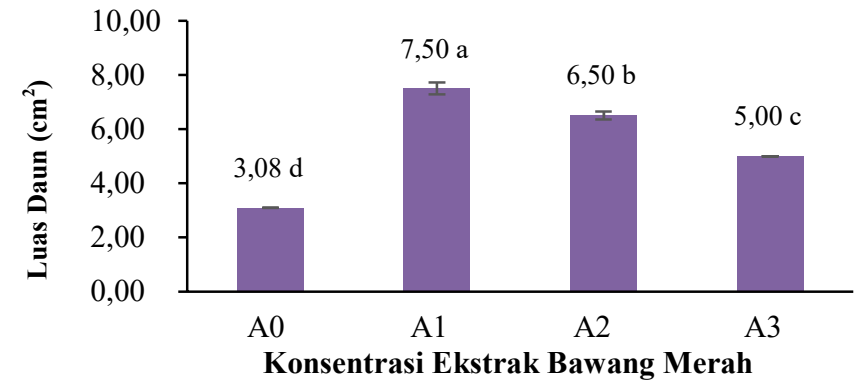

Gambar 4. Pengaruh Konsentrasi Ekstrak Bawang Merah terhadap Variabel Luas Daun

Berdasarkan hasil uji jarak berganda Duncan (DMRT $\alpha$ 5\%) (Gambar 4) menunjukkan bahwa terdapat perbedaan yang nyata pada semua perlakuan ekstrak bawang merah. Perlakuan konsentrasi ekstrak bawang merah sebesar $0,5 \%$ (A1) menunjukkan rata-rata luas daun tertinggi yakni sebesar $7,05 \mathrm{~cm} 2$, sedangkan terendah pada perlakuan kontrol (A0) sebesar $3,08 \mathrm{~cm} 2$. Perbedaan antara perlakuan ekstrak bawang merah konsentrasi $0,5 \%$ (A1) dengan konsentrasi kontrol (A0) menunjukkan selisih rata-rata luas daun sebesar 4,42 cm2. Perlakuan konsentrasi ekstrak bawang merah sebesar $0,5 \%$ (A1) menunjukkan hasil yang lebih baik dibandingkan dengan kontrol (A0), konsentrasi 1,0\% (A2), dan konsentrasi 1,5\% (A3).

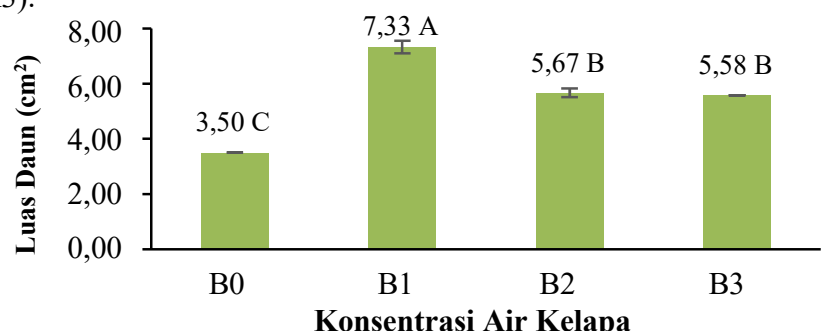

Gambar 5. Pengaruh Konsentrasi Air Kelapa terhadap Variabel Luas Daun

Berdasarkan hasil uji berganda Duncan (DMRT $\alpha$ 5\%) (Gambar 5) menunjukkan bahwa terdapat perbedaan yang nyata pada semua perlakuan konsentrasi air kelapa. Perlakuan konsentrasi air kelapa sebesar $20 \%$ (B1) menunjukkan rata- rata luas daun tertinggi yakni sebesar 7,33 $\mathrm{cm} 2$, sedangkan terendah pada perlakuan konsentrasi kontrol (B0) sebesar 3,50 $\mathrm{cm} 2$. Perbedaan antara perlakuan air kelapa konsentrasi $20 \%$ (B1) dengan konsentrasi kontrol (B0) menunjukkan selisih rata-rata luas daun sebesar 3,83 $\mathrm{cm} 2$. Perlakuan konsentrasi air kelapa sebesar $20 \%$ (B1) menunjukkan hasil yang lebih baik dibandingkan dengan kontrol (B0), perlakuan konsentrasi 30\% (B2), dan konsentrasi $40 \%$ (B3).

\section{Panjang Akar}

Perlakuan konsentrasi ekstrak bawang merah dan perlakuan air kelapa memberikan pengaruh berbeda sangat nyata terhadap variabel panjang akar, akan tetapi interaksi kedua perlakuan memberikan pengaruh berbeda tidak nyata terhadap variabel panjang akar.

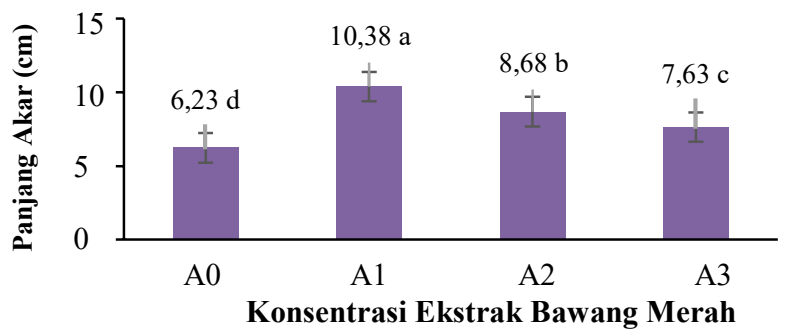

Gambar 6. Pengaruh Konsentrasi Ekstrak Bawang Merah terhadap Variabel Panjang Akar
Berdasarkan hasil uji jarak berganda Duncan (DMRT $\alpha 5 \%$ ) (Gambar 6) menunjukkan bahwa terdapat perbedaan yang nyata pada semua perlakuan ekstrak bawang merah. Perlakuan konsentrasi ekstrak bawang merah sebesar $0,5 \%$ (A1) menunjukkan rata-rata panjang akar tertinggi yakni sebesar $10,38 \mathrm{~cm}$, sedangkan terendah pada perlakuan kontrol (A0) sebesar $6,23 \mathrm{~cm}$. Perbedaan antara perlakuan ekstrak bawang merah konsentrasi $0,5 \%$ (A1) dengan konsentrasi kontrol (A0) menunjukkan selisih rata-rata panjang akar sebesar $4,15 \mathrm{~cm}$. Perlakuan konsentrasi ekstrak bawang merah sebesar $0,5 \%$ (A1) menunjukkan hasil yang lebih baik dibandingkan dengan kontrol (A0), konsentrasi 1,0\% (A2), dan konsentrasi 1,5\% (A3).

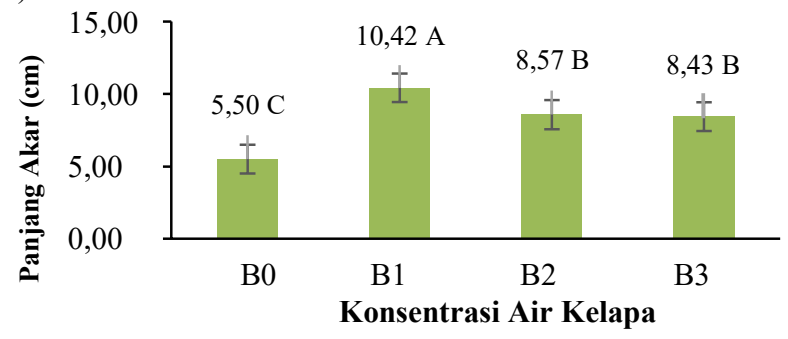

Gambar 7. Pengaruh Konsentrasi Air Kelapa terhadap Variabel Panjang Akar

Berdasarkan hasil uji berganda Duncan (DMRT $\alpha$ 5\%) (Gambar 7) menunjukkan bahwa terdapat perbedaan yang nyata pada semua perlakuan konsentrasi air kelapa. Perlakuan konsentrasi air kelapa sebesar $20 \%$ (B1) menunjukkan rata- rata panjang akar tertinggi yakni sebesar $10,42 \mathrm{~cm}$, sedangkan terendah pada perlakuan konsentrasi kontrol (B0) sebesar $5,50 \mathrm{~cm}$. Perbedaan antara perlakuan air kelapa konsentrasi $20 \%$ (B1) dengan konsentrasi kontrol (B0), konsentrasi 1,0\% (B2), dan konsentrasi $1,5 \%$ (B3) menunjukkan selisih rata-rata panjang akar sebesar 4,92 $\mathrm{cm}$. Perlakuan konsentrasi air kelapa sebesar 20\% (B1) menunjukkan hasil yang lebih baik dibandingkan dengan kontrol (B0), perlakuan konsentrasi 30\% (B2), dan konsentrasi 40\% (B3).

\section{Jumlah Akar}

Perlakuan konsentrasi ekstrak bawang merah dan perlakuan air kelapa memberikan pengaruh berbeda sangat nyata terhadap variabel jumlah akar, akan tetapi interaksi kedua perlakuan memberikan pengaruh berbeda tidak nyata terhadap variabel jumlah akar.

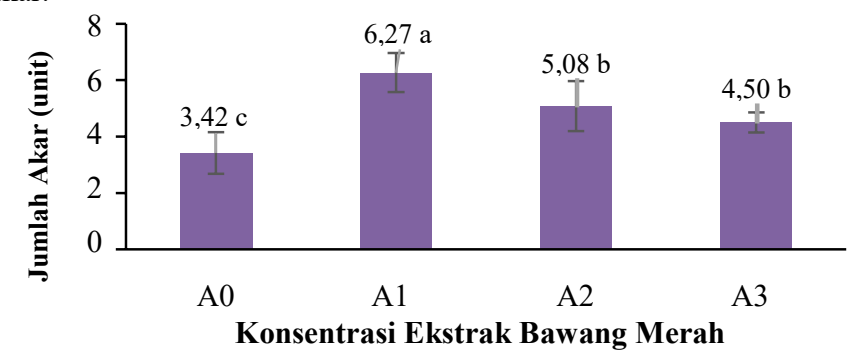

Gambar 8. Pengaruh Konsentrasi Ekstrak Bawang Merah terhadap Variabel Jumlah Akar

Berdasarkan hasil uji jarak berganda Duncan (DMRT $\alpha$ 5\%) (Gambar 8) menunjukkan bahwa terdapat perbedaan yang nyata pada semua perlakuan ekstrak bawang merah. Perlakuan konsentrasi ekstrak bawang merah sebesar $0,5 \%$ (A1) menunjukkan rata-rata jumlah akar tertinggi yakni sebesar 6,27 unit, sedangkan terendah pada perlakuan kontrol (A0) sebesar 3,42 unit. Perbedaan antara perlakuan ekstrak bawang merah konsentrasi $0,5 \%$ (A1) dengan konsentrasi kontrol (A0) menunjukkan selisih rata-rata jumlah akar sebesar 2,85 unit. Perlakuan konsentrasi ekstrak bawang merah sebesar $0,5 \%$ (A1) menunjukkan hasil yang lebih baik dibandingkan dengan kontrol (A0), konsentrasi 1,0\% (A2), dan konsentrasi 1,5\% (A3). 


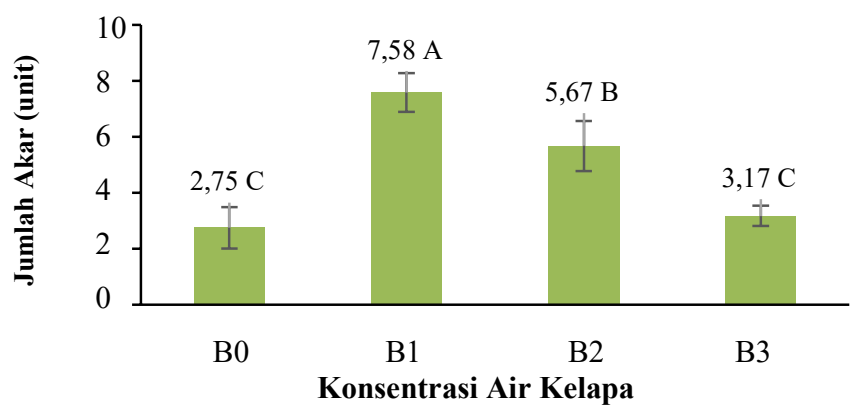

Gambar 9. Pengaruh Konsentrasi Air Kelapa terhadap Variabel Jumlah Akar

Berdasarkan hasil uji berganda Duncan (DMRT a 5\%) (Gambar 9) menunjukkan bahwa terdapat perbedaan yang nyata pada semua perlakuan konsentrasi air kelapa. Perlakuan konsentrasi air kelapa sebesar $20 \%$ (B1) menunjukkan rata- rata jumlah akar paling banyak yakni sebesar 7,58 unit, sedangkan terendah pada perlakuan konsentrasi kontrol (B0) sebesar 2,75 unit. Perbedaan antara perlakuan air kelapa konsentrasi $20 \%$ (B1) dengan konsentrasi kontrol (B0) menunjukkan selisih rata-rata jumlah akar sebesar 4,83 unit. Perlakuan konsentrasi air kelapa sebesar 20\% (B1) menunjukkan hasil yang lebih baik dibandingkan dengan kontrol (B0), perlakuan konsentrasi 30\% (B2), dan konsentrasi 40\% (B3).

\section{Berat Kering Akar}

Perlakuan konsentrasi ekstrak bawang merah dan perlakuan air kelapa memberikan pengaruh berbeda sangat nyata terhadap variabel berat kering akar, akan tetapi interaksi kedua perlakuan memberikan pengaruh berbeda tidak nyata terhadap variabel berat kering akar.

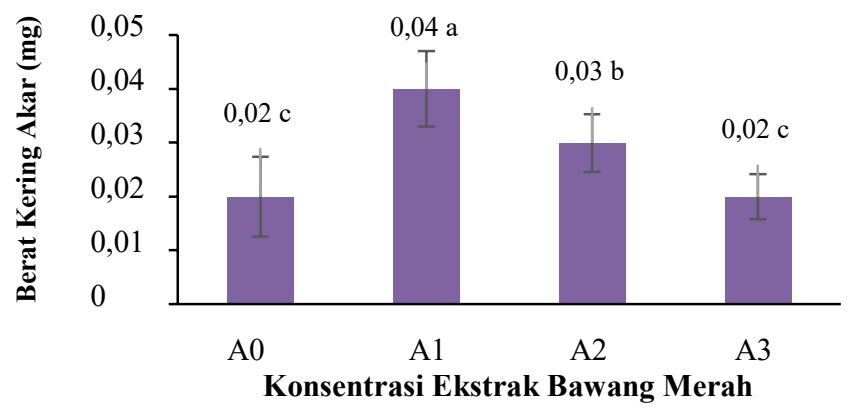

\section{Gambar 10. Pengaruh Konsentrasi Ekstrak Bawang Merah} terhadap Variabel Berat Kering Akar

Berdasarkan hasil uji jarak berganda Duncan (DMRT $\alpha 5 \%$ ) (Gambar 10) menunjukkan bahwa terdapat perbedaan yang nyata pada semua perlakuan ekstrak bawang merah. Perlakuan konsentrasi ekstrak bawang merah sebesar $0,5 \%$ (A1) menunjukkan rata-rata jumlah akar tertinggi yakni sebesar $0,04 \mathrm{mg}$, sedangkan terendah pada perlakuan kontrol (A0) dan konsentrasi $1,5 \%$ (A3) sebesar 0,02 mg. Perbedaan antara perlakuan ekstrak bawang merah konsentrasi $0,5 \%$ (A1) dengan konsentrasi kontrol (A0) dan konsentrasi $1,5 \%$ (A3) menunjukkan selisih rata-rata berat kering akar sebesar 0,02 mg. Perlakuan konsentrasi ekstrak bawang merah sebesar $0,5 \%$ (A1) menunjukkan hasil yang lebih baik dibandingkan dengan kontrol (A0), konsentrasi 1,0\% (A2), dan konsentrasi 1,5\% (A3).

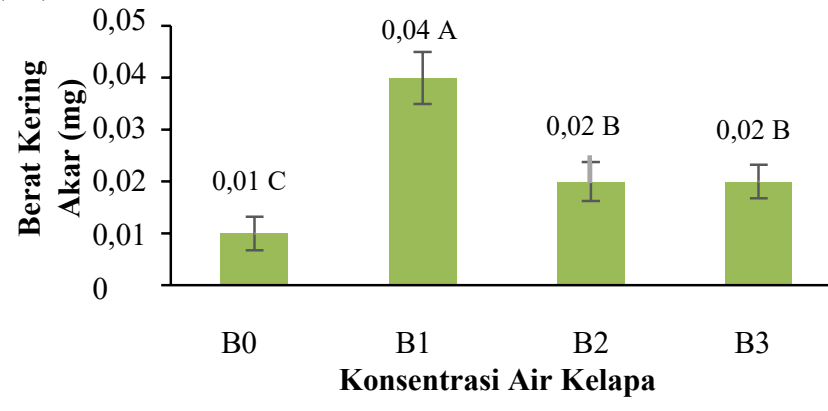

Gambar 11. Pengaruh Konsentrasi Air Kelapa terhadap Variabel Berat Kering Akar

Berdasarkan hasil uji berganda Duncan (DMRT $\alpha$ 5\%) (Gambar 111) menunjukkan bahwa terdapat perbedaan yang nyata pada semua perlakuan konsentrasi air kelapa. Perlakuan konsentrasi air kelapa sebesar 20\% (B1) menunjukkan rata- rata berat kering akar tertinggi yakni sebesar $0,04 \mathrm{mg}$, sedangkan terendah pada perlakuan konsentrasi kontrol (B0) sebesar 0,01 mg. Perbedaan antara perlakuan air kelapa konsentrasi $20 \%$ (B1) dengan konsentrasi kontrol (B0) menunjukkan selisih rata-rata berat kering akar sebesar 0,03 mg. Perlakuan konsentrasi air kelapa sebesar 20\% (B1) menunjukkan hasil yang lebih baik dibandingkan dengan kontrol (B0), perlakuan konsentrasi 30\% (B2), dan konsentrasi $40 \%$ (B3).

\section{Berat Kering Daun}

Perlakuan air kelapa memberikan pengaruh berbeda sangat nyata terhadap variabel berat kering daun, akan tetapi interaksi kedua perlakuan dan pengaruh tunggal ekstrak bawang merah memberikan pengaruh berbeda tidak nyata, terhadap variabel berat kering daun.

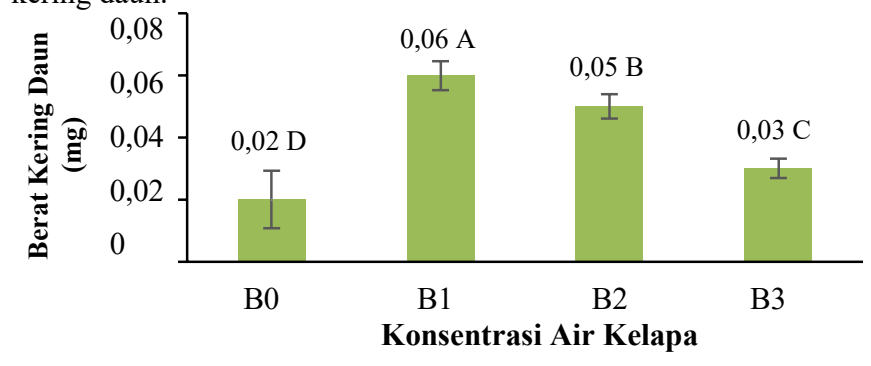

Gambar 12. Pengaruh Konsentrasi Air Kelapa terhadap Variabel Berat Kering Daun

Berdasarkan hasil uji berganda Duncan (DMRT a $5 \%$ ) (Gambar 12) menunjukkan bahwa terdapat perbedaan yang nyata pada semua perlakuan konsentrasi air kelapa. Perlakuan konsentrasi air kelapa sebesar 20\% (B1) menunjukkan rata- rata berat kering daun tertinggi yakni sebesar $0,06 \mathrm{mg}$, sedangkan terendah pada perlakuan konsentrasi kontrol (B0) sebesar 0,02 mg. Perbedaan antara perlakuan air kelapa konsentrasi $20 \%$ (B1) dengan konsentrasi kontrol (B0) menunjukkan selisih rata-rata berat kering daun sebesar 0,04 mg. Perlakuan konsentrasi air kelapa sebesar 20\% (B1) menunjukkan hasil yang lebih baik dibandingkan dengan kontrol (B0), perlakuan konsentrasi 30\% (B2), dan konsentrasi $40 \%$ (B3)

Berdasarkan hasil penelitian (Tabel 1) terdapat interaksi antara perlakuan konsentrasi ekstrak bawang merah dan air kelapa, diperoleh hasil berbeda nyata pada variabel waktu terbentuknya tunas. Hal tersebut diduga karena terdapat hubungan yang saling berkaitan antara konsentrasi ekstrak bawang merah dan air kelapa yang dikombinasikan, sehingga berpengaruh terhadap variabel waktu terbentuknya tunas. Hal ini sesuai dengan hasil penelitian Trisnawan et al. (2017) bahwa zat pengatur tumbuh alami ekstrak bawang merah dan air kelapa muda dapat menstimulasi pemecahan dormansi tunas pada hasil okulasi tanaman jeruk. Keseimbangan hormon juga diperlukan sebagai salah satu faktor yang memberikan pengaruh terhadap laju pertumbuhan mata tunas, dimana hormon yang dibutuhkan tidak hanya sitokinin melainkan juga dibutuhkan hormon auksin dan giberelin dalam proses laju pertumbuhan tersebut (Trisna et al. dalam Trisnawan et al., 2017).

Salah satu indikator keberhasilan dalam pertumbuhan stek yaitu terbentuknya tunas. Hal ini sesuai dengan Febriana (2009) bahwa pembentukan tunas terjadi karena adanya proses morfogenesis antara interaksi pertumbuhan dengan diferensiasi oleh beberapa sel pemacu terbentuknya organ. Tunas tersebut juga merupakan tahapan penting dalam pembentukan primordia daun pada pertumbuhan stek. Daun merupakan organ tanaman yang memiliki jumlah klorofil terbesar untuk proses fotosintesis tanaman. 
Fotosintesis tersebut akan menghasilkan karbohidrat yang merupakan sumber energi sebagai penunjang pertumbuhan tanaman. Berdasarkan hasil penelitian pada pengaruh faktor tunggal bahwa variabel panjang tunas, luas daun, panjang akar, jumlah akar, dan berat kering akar menunjukkan hasil yang berbeda nyata pada konsentrasi ekstrak bawang merah $0,5 \%$. Setiap tanaman memiliki kandungan auksin endogen, namun memiliki ketersediaan dalam jumlah yang sedikit, sehingga diperlukan penambahan auksin dari luar (eksogen) untuk meningkatkan pertumbuhan stek. Hal ini sesuai dengan pernyataan Albersheim et al. dalam Annadurai dan Motlag (1999) bahwa fitohormon atau hormon endogen pada tanaman dipertahankan pada taraf yang rendah. Penambahan auksin secara eksogen harus disesuaikan dengan jenis, kandungan, serta konsentrasi yang akan diaplikasikan. Konsentrasi ekstrak bawang merah yang tepat akan dapat meningkatkan aktivitas hormon endogen seperti 2,4-D dan asam indol asetat (IAA) (Spear dan Thimann, 1949).

Penggunaan umbi bawang merah hasil panen pada penelitian memiliki ketersediaan auksin yang sedikit. Hal ini sesuai dengan pernyataan Annadurai dan Motlag (1999) bahwa kandungan auksin pada daun bawang normal berumur

4 hari sebesar $200,25 \mu \mathrm{g} / \mathrm{ml}$, sedangkan kandungan auksin pada daun bawang normal berumur 20 hari sebesar 4,50

$\mu \mathrm{g} / \mathrm{ml}$. Kandungan auksin tersebut pada daun bawang normal secara gradual menurun dengan sejalan umur tanaman, karena auksin endogen telah tersebar menyeluruh ke organ tanaman sebagai penunjang pertumbuhan dan perkembangan tanaman.

Selain itu menurut Muswita (2011) bahwa dalam eksrak bawang merah tidak hanya terdapat kandungan hormon sitokinin dan auksin, melainkan juga mengandung sikloaliin, metilaliin, dihidroalliin, flavonglikosida, kuersetin, saponin, peptida, minyak atsiri, vitamin dan zat pati dimana semua kandungan tersebut memiliki peran dalam proses metabolisme tanaman. Menurut Bambang dalam Achmad (2016) bahwa Gugus kimia seperti dihidroalin termasuk kedalam golongan zeatin dimana berfungsi dalam pembelahan sel yaitu merangsang pembentukan tunas dan akar baru pada stek tanaman, sehingga stek berpeluang untuk tumbuh menjadi tanaman baru akan lebih besar.

Berdasarkan hasil penelitian pada pengaruh faktor tunggal bahwa variabel panjang tunas, jumlah daun, luas daun, panjang akar, jumlah akar, berat kering akar, dan berat kering daun menunjukkan hasil yang berbeda nyata pada konsentrasi air kelapa $20 \%$. Hal ini diduga karena adanya terdapat kandungan hormon auksin, sitokinin, dan giberelin dalam konsentrasi air kelapa $20 \%$ cukup optimal untuk merangsang dan meningkatkan pertumbuhan stek jambu air madu deli hijau dibandingkan konsentrasi 30\% dan konsentrasi $40 \%$. Hal ini sesuai dengan pernyataan Karimah dalam Mayura et al. (2016) bahwa kandungan sitokinin pada air kelapa muda lebih besar yaitu sebesar $5,8 \mathrm{mg} /$ liter lebih tinggi dibandingkan kandungan auksinnya yaitu besar $0,07 \mathrm{mg} / \mathrm{liter}$. Pembentukan tunas dan diferensiasi sel berlangsung apabila terdapat interaksi dimana konsentrasi sitokinin lebih besar dibandingkan konsentrasi auksin (Widiastoety et al. dalam Mayura et al., 2016).

Perlakuan konsentrasi air kelapa 20\% merupakan konsentrasi yang tidak terlalu tinggi dibandingkan konsentrasi $30 \%$ dan $40 \%$, sehingga konsentrasi $20 \%$ cukup efektif dan optimal untuk merangsang pertumbuhan awal stek yaitu inisiasi akar dan tunas stek. Penentuan konsentrasi air kelapa tersebut sangat penting dalam merangsang dan meningkatkan pertumbuhan stek. Apabila konsentrasi air kelapa yang diaplikasikan tidak tepat, maka akan menghambat pertumbuhan stek tersebut. Konsentrasi air kelapa yang tinggi akan dapat membuat larutan menjadi lebih pekat, sehingga menyebabkan proses pertumbuhan stek terhambat. Hal ini sesuai dengan pernyataan Khair et al. (2013) kandungan auksin didalam air kelapa mampu membuat sel sklerenkim mengalami pelunakan, kemudian apabila berlebihan maka akan merusak sel dimana menyebabkan sel permukaan tunas terhambat, sulit tumbuh, berakibat plasmolisis, dan bahkan stek mati.

Selain itu peningkatan pertumbuhan stek dikarenakan adanya kandungan unsur hara seperti fosfor, kalsium, dan besi, serta adanya kandungan vitamin pada air kelapa muda. Hal ini sesuai dengan pernyataan Puspita dalam Mustakim (2015) bahwa unsur kalsium pada air kelapa berperan dalam pembentukan bulu-bulu akar dan pemanjangan akar. Golongan vitamin B1 dengan jenis tiamin juga berfungsi mempercepat pembelahan sel pada meristem akar (Salisbury dan Ross, 1995).

Berdasarkan hasil penelitian dapat diambil kesimpulan bahwa ekstrak bawang merah dan air kelapa memberikan pengaruh terhadap pertumbuhan stek pucuk jambu air madu deli hijau. Interaksi antara konsentrasi ekstrak bawang merah 0,5\% dengan konsentrasi air kelapa $20 \%$ menunjukkan pengaruh yang lebih baik terhadap variabel waktu terbentuknya tunas. Pemberian konsentrasi ekstrak bawang merah $0,5 \%$ secara keseluruhan menunjukkan pengaruh yang baik terhadap variabel panjang tunas, luas daun, panjang akar, jumlah akar, dan berat kering akar. Pemberian konsentrasi air kelapa 20\% secara keseluruhan menunjukkan pengaruh yang baik terhadap variabel panjang tunas, jumlah daun, luas daun, panjang akar, jumlah akar, berat kering akar, dan berat kering daun.

\section{KESIMPULAN}

Hasil penelitian menunjukkan kombinasi perlakuan terbaik untuk konsentrasi ekstrak bawang merah dan air kelapa adalah konsentrasi $0,5 \%$ dan air kelapa $20 \%$.

\section{DAFTAR PUSTAKA}

Achmad, B. 2016. Efektivitas Rooton-F, Air Kelapa Muda, dan Ekstrak Bawang Merah dalam Merangsang Pertumbuhan Stek Batang Pasak Bumi. Hutan Tropis, 4 (3): 224-231.

Annadurai, B. and D. B. Motlag. 1999. Estimation of Phytohormones in Normal and Infected Onion Leaves By Alternaria Cepulae. Biojournal, 11 (1): 155-160.

Djamhuri, E. 2011. Pemanfaatan Air Kelapa untuk Meningkatkan Pertumbuhan Stek Pucuk Meranti Tembaga (Shorea leprosula Miq.). Silvikutltur Tropika, 2 (1): 5-8.

Febriana, S. 2009. Pengaruh Konsentrasi ZPT dan Panjang Stek terhadap Pembentukan Akar dan Tunas pada Apokad (Persea americana Mill). Bogor: Institut Pertanian Bogor.

Hadiati, S. 2011. Pengaruh Konsentrasi BAP Terhadap Pertumbuhan Stek Batang Nenas (Ananas comosus. L). Agrin, 15 (2): 127-132.

Karo-karo, F. J., A. Barus., dan M. K. Bangun. 2015. Pengaruh Komposisi Media Tanam dan Interval Penyiraman Terhadap Pertumbuhan Bibit Jambu Air Madu Deli Hijau (Syzigium samarengense). Agroteknologi, 4 (1): 1786-1795.

Khair, H., Meizal, dan Z. R. Hamdani. 2013. Pengaruh Konsentrasi Ekstrak Bawang Merah dan Air Kelapa terhadap Pertumbuhan Stek Tanaman Melati Putih (Jasminum sambac L.). Agrium, 18 (2): 130-138.

Mayura, E., Yudarfis, H. Idris, dan I. Darwati. 2016. Pengaruh Pemberian Air Kelapa dan Frekuensi Pemberian Terhadap Pertubuhan Benih Cengkeh. Littro, 27 (2): 123-128.

Mendrofa, R. 2018. Respon Pertumbuhan Stek Pucuk Tanaman Jambu Air Deli Hijau (Syzygium Agueum) dengan Pemberian Zat Pengatur Tumbuh Sintetis (ZPT) Atonik dan ZPT Alami Bonggol Pisang dan Bawang Merah. Universitas Medan Area: Fakultas Pertanian

Mulyani, C., dan J. Ismail. 2015. Pengaruh Konsentrasi dan Lama Perendaman Rootone F terhadap Pertumbuhan Stek Pucuk 
Jambu Air (Syzygium semaragense) pada Media Oasis. Agrosamudra, 2 (2): 1-9.

Mustakim., B. F. Wahidah., dan A. Al-fauzy. 2015. Pengaruh Penambahan Air Kelapa Terhadap Pertumbuhan Stek Mikro Tanaman Krisan (Crysanthemum indicum)

Secara In Vitro. Mikrobiolgi Kesehatan dan Lingkungan, 1 (1): 181-187.

Muswita. 2011. Pengaruh Konsentrasi Bawang Merah (Allium cepa L.) terhadap Pertumbuhan Setek Gaharu (Aquilaria malaccencis OKEN). Penelitian Universitas Jambi Seri Sains, 13 (1): 15-20.

Rangkuti, T. N., I. A. Kadir., dan Indra. 2016. Prospek Pengembangan Budidaya Jambu Madu Deli Hijau di Kelurahan Sumber Karya Kecamatan Binjai Timur Kota Binjai (Studi Kasus Pada Usaha Rizki Jambu Madu). Ilmiah Mahasiswa Pertanian Unsyiah, 1 (1): 439-451.

Salisbury, F. B., dan C. W. Ross. 1995. Fisiologi Tumbuhan.

Bandung: ITB.

Sinaga, N. F., F. E. Sitepu, dan Meiriani. 2015. Pertumbuhan Setek Jambu Air Deli Hijau (Syzygium samarangense (Blume) Merr. \& Perry) dengan Bahan Tanam dan Konsentrasi IBA (Indole Butyric Acid) Yang Berbeda. Agroteknologi, 4 (1): 1872-1880.

Spear, I., and K. V. Thimann. 1949. The Effect of Onion Juice on the Growth Response to Auxin. Plant Physiolgy, 1 (1): $587-$ 600 .

Sudomo, A., A. Rohandi, dan N. Mindawati. 2013. Penggunaan Zat Pengatur Tumbuh Pada Stek Pucuk Manglid Rootone-F (Manglietia glauca BI). Hutan Tanaman, 10 (2): 57-63.

Trisnawan, A. S., A. Sugiyatno, S. Fajriani dan L. Setyobudi. 2017. Pengaruh Pemberian Zat Pengatu Tumuh pada Pematahan Dormansi Mata Tunas Tanaman Jeruk (Citrus sp.) Budding. Produksi Tanaman, 5 (5): 742-747. 
